ISSN 2078-6441. Вісник Львівського університету. Серія географічна. 2013. Випуск 41. С. 132-139. Visnyk of the Lviv University. Series Geography. 2013. Issue 41. P. 132-139.

631.48 (477.75)

\author{
лен ргін \\ врійський н ціон льний університет ім. . . ерн дського, \\ просп. к демік ерн дського, 4, 95007, м. імферополь, кр їн, \\ e-mail:YazcivLena@rambler.ru
}

озглянуто основні термодин мічні т енергетичні $\mathrm{x}$ р ктеристики грунтоутворюв льних субстр тів і різновікових грунтів римського півостров, які можн використовув ти як пок зники потенційної зд тності гірських порід до грунтоутворення т с мовідновлення порушених грунтів у р зі розробки стр тегій рекультив ції земель. оведено, що з термодин мічних позицій грунтоутворення - це процес з кономірного збільшення термодин мічних т енергетичних х $\mathrm{p}$ ктеристик субстр ту, н якому формуються грунти.

лючові слов : енергія крист лічної гр тки, вільн енергія іббс , ентропія, грунтоутворення.

нергетичний т термодин мічний підхід до вивчення природних процесів, у тому числі грунтоутворення отримує ост ннім ч сом щор з більшого поширення, дже, як з зн ч $є$. ихоненко "грунтогенез є скл дним нтиентропійним біо-гео-фізикохімічним процесом екзогенного перетворення н поверхні емлі речовин т енергії, причетним до формув ння з неродючої породи якісно нового, н діленого родючістю природного тіл - грунту" [2, с. 46]. ому цік вим є вивчення процесів грунтоутворення з енергетичного т термодин мічного поглядів.

кту льність цього н пряму досліджень зумовлен можливістю використ ння уявлень про термодин міку грунтів т субстр тів, зокрем енергію крист лічних гр ток мінер лів, вільну енергію іббс т ентропію, для оцінки потенційної зд тності гірських порід до грунтоутворення. ю проблему вивч ло б г то грунтозн вців $[1,7,9,13]$. дн к для грунтоутворюв льних порід т грунтів риму т кі роботи не виконув ли. е й зумовило н шу мету - оцінити енергетичні т термодин мічні х р ктеристики різновікових грунтів і грунтоутворюв льних порід римського півостров 3 погляду їхнього впливу н суч сний грунтоутворюв льний процес.

. олобуєв енергію крист лічної гр тки визн чив як “кількість енергії, яку потрібно $з$ тр тити для руйнув ння однієї гр м-молекули крист лічної речовини до ст ну г зоподібних одно томних іонів, що безкр йньо відд лені один від одного” [1, с. 89]. ільн енергія іббс - в жлив термодин мічн х р ктеристик, що визн ч є ту ч стину енергії, з вдяки якій з відповідних умов може виконув тись корисн робот [7]. перше поняття ентропія введене 1865 р. . л узіусом у термодин міці для визн чення міри незворотного розсіюв ння енергії. нтропія - це функція ст ну системи, тобто кожному ст ну можн пост вити у відповідність цілком певне зн чення ентропії [10].

етодичною основою для н шої роботи ст ли пр ці. ерсм н [16] т . олобуєв [1]. окрем , . олобуєв у р зі оцінюв ння термодин мічних пок зників 3 пропонув в ув ж ти мінер льну ч стину грунту сумою оксидів т для розр хунків

(C) ргін ., 2013 
енергії крист лічної гр тки т вільної енергії іббс використовув ти д ні в лового хімічного скл ду мінер льної ч стини грунту [1, с. 89]. ме 3 з стосув нням цього методичного прийому вели под льші розр хунки. н логічно треб вв ж ти, що термодин мічні вл стивості грунтоутворюв льних порід доцільно розр ховув ти з н веденою вище методикою, оскільки ми вивч ємо субстр т, більше чи менше перетворений процес ми грунтоутворення. н чення енергії крист лічних гр ток в окремих оксид х н ведено в т блицях, що розр хов ні . ерсм ном [16]. кщо д них для окремих оксидів не було, то ми розр ховув ли енергію крист лічних гр ток 3 емпіричними формул ми [8]. онст нти вільної енергії н ведені в термодин мічних довідник х [4, 10, 15]. нергетичні т термодин мічні х р ктеристики основних грунтоутворюв льних порід римського півостров розр ховув ли з результ т ми в лових н лізів різновікових грунтів, грунтоутворюв льних порід т субстр тів нтропогенного походження різного віку, н яких формуються грунти, н території д внього межув ння ерсонеської хори н ер клійському півострові, грунтів, що сформув лись н 3 лишк х д вньої фортеці р кс, середньовічної фортеці емб ло, т кож зон льних повноголоценових грунтів н мис $\mathrm{x}$ йя, ртьян т 3 використ нням д них, що н ведені в пр цях . зенс- итовської [3], . очкін [12], . оловицького [14].

езульт ти розр хунків енергії крист лічної гр тки, енергії іббс в основних грунтоутворюв льних пород $\mathrm{x}$ римського півостров гр фічно пок 3 но н рис. 1.

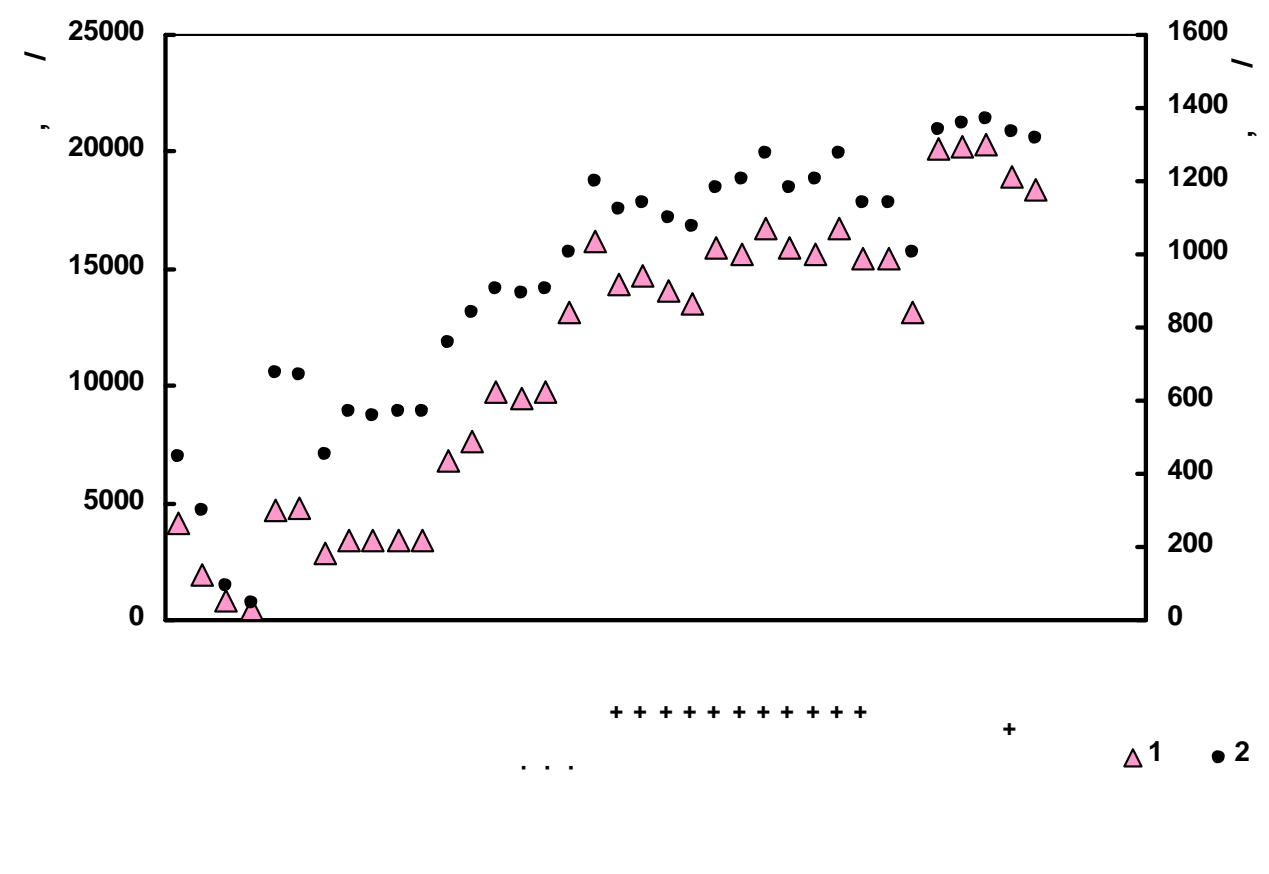

ис. 1. нергія крист лічної гр тки (1) т енергія іббс (2) для основних грунтоутворюв льних порід римського півостров .

н ліз рис. 1 свідчить, що з з п с ми енергії крист лічної гр тки т вільної енергії іббс грунтоутворюв льні породи римського півостров формують дві групи. ершу утворюють щільні гірські породи, головно в пняки, мергелі. руг груп - це перев ж- 
но полімінер льні пухкі гірські породи, головно глини, суглинки, т кож конгломер ти т пісковики. нергія крист лічної гр тки, вільн енергія іббс т ентропія в групі щільних грунтоутворюв льних порід зн чно менш , ніж у групі пухких порід. нергія крист лічної гр тки змінюється від 454 до 7747 к ж/г, вільн енергія іббс - від 490 до $840 \mathrm{k}$ ж/Г, зн чення ентропії - від $43 \mathrm{k}$ ж/Гхгр д до $35,6 \mathrm{~K}$ ж/гхгр д. групі, що скл д ється з пухких грунтоутворюв льних порід, внутрішня енергія зн чно більш , ніж енергія крист лічної гр тки, - 9200-20280 к ж/г, вільн енергія іббс 860-1 $370 \mathrm{~K}$ ж/г, зн чення ентропії колив ється в меж х від 48,0 до 66,0 к ж/гХгр д. убстр ти нтропогенного походження з йм ють перехідні ділянки між групою щільних к рбон тних порід т пухких. е зумовлено тим, що грунтоутворюв льні субстр ти під грунт ми, які сформув лись н пл нт жних ділянк х д внього розмежув ння (клеp х) ерсонеської хори н території ер клійського півостров, скл д ються з суміші крихти в пнякових порід т грунту, який $з$ кл д ли в пл нт жз системи впорядкув ння д внього сільськогоспод рського освоєння.

орівняння зн чень енергії крист лічної гр тки (U) з процентною ч сткою співвідношення вільної енергії іббс т енергії гр тки (G/U) (рис. 2 ) д ло змогу виявити, що точки н гр фіку розт шов ні в двох полях. б'єкти в пр вому нижньому секторі (див. рис. 2 , 1) м ють високі зн чення енергії крист лічної гр тки, одн к ч стк вільної енергії, як може перетворюв тись у роботу, менш . е груп суглинків т глин.

вп ки, породи, що з йм ють верхній лівий сектор поля (див. рис. 2 , 2), м ють меншу енергію гр тки, проте більшу вільну енергію, що зд тн перетворюв тись у роботу.
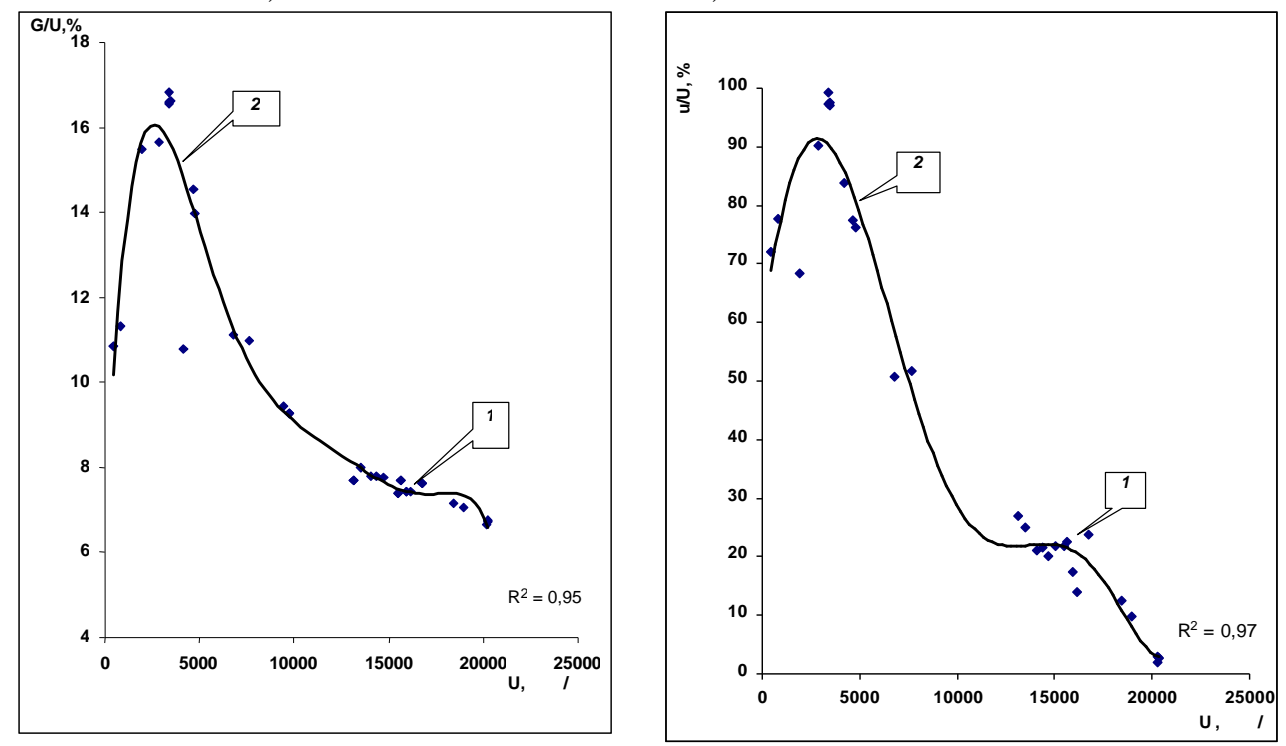

A

ис. 2. лежність енергії крист лічної гр тки (U) від ч стки співвідношення енергії іббс т енергії крист лічної гр тки $(\mathrm{G} / \mathrm{U})($ ) т від ч стки співвідношення енергії безкремнеземної ч стини й енергії гр тки (u/U) ( ).

н ліз співвідношення енергії крист лічної гр тки (U) і ч стки безкремнеземної енергії (u/U, де u - енергія гр тки без окислів кремнію) з свідчив, що породи, у скл ді яких $є$ незн чн кількість кремнезему (в пняки, мергелі), м ють невеликі зн чення ене- 
ргії крист лічної гр тки (див. рис. 2 , 2), з підвищенням вмісту кремнію в породі (глини, суглинки), енергія їхньої крист лічної гр тки збільшується (див. рис. 2 , 1).

озглянуті з кономірності д ють підст ви стверджув ти, що полімінер льні пухкі гірські породи т конгломер ти, пісковики створюють досить сприятливі умови для їхнього біологічного освоєння, у них більш ре кційн зд тність до змін умов середовищ, ун слідок процесів первинного т вторинного звітрюв ння вивільняеться зн чн кількість енергії, що може витр ч тися для формув ння нових грунтів н об'єкт х, що скл д ються з т ких субстр тів, н прикл д, н відв л х к р'єрів, ділянк х з мех нічно порушеним грунтовим покривом тощо. ме цими вл стивостями грунтоутворюв льних порід ми пояснюємо високі зн чення швидкостей формув ння грунту н поч ткових ет п х освоєння території - від 1,4-1,2 мм/рік н піск х р б тської трілки [6] до 0,8-1,2 мм/рік н суглинк х урецького лу [5].

грунт х (див. т бл. 1, рис. 3) н йвищі зн чення енергії крист лічної гр тки т вільної енергії іббс прит м нні зон льним повноголоценовим н лог м: це к шт нові грунти, чорноземи передгірські к рбон тні, чорноземи південні т коричневі грунти.

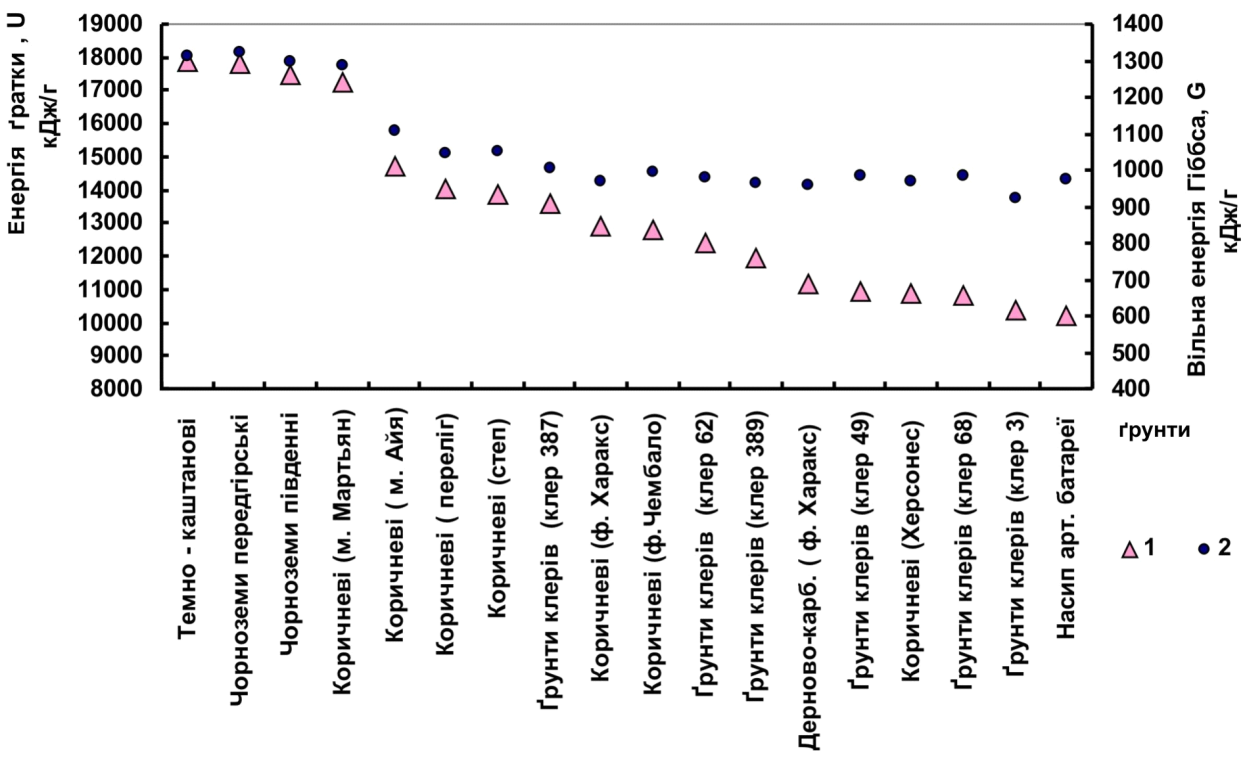

ис. 3. нергія крист лічної гр тки (1) т енергія іббс (2) для грунтів римського півостров .

ксим льні зн чення енергій гр тки простежуються в к шт нових грунт х 17857 к ж/г, мінім льні в коричневих - 17264 к ж/г. енші зн чення термодин мічних х р ктеристик прит м нні різновіковим грунт м що сформов ні: н клер х - д вніх сільськогоспод рських н діл $\mathrm{x}$ н території ерсонеської держ ви, віком 2000 років; н руїн х середньовічних фортець р кс віком 2500 років т емб ло віком 500 років; н молодших субстр т х нтропогенного походження (див. т бл. 1). н чення енергії гр тки змінюються від 1356 до 10184 к ж/г, що м йже в 1,7 р 3 менше, ніж у зон льних грунт х, зн чення енергії іббс колив ються в меж х від 1007 до $974 \mathrm{k}$ ж/г, тоді як у зон льних коричневих грунт х 11 зн чення дорівнює $1107 \mathrm{~K}$ Ж/Г. 

ISSN 2078-6441. Вісник Львівського університету. Серія географічна. 2013. Випуск 41

блиця 1

ермодин мічні х р ктеристики грунтів римського півостров

\begin{tabular}{|c|c|c|c|c|c|c|}
\hline рунти & $\begin{array}{r}\text { iк, } \\
\text { роки }\end{array}$ & $\begin{array}{c}\text { нергія } \\
\text { гр тки, U }\end{array}$ & $\begin{array}{c}\text { нергія } \\
\text { іббс, } \mathrm{G}\end{array}$ & $\begin{array}{c}\text { нтропія, } \\
\text { к ж/гхгр д }\end{array}$ & $\mathrm{G} / \mathrm{U}$, & $\mathrm{u} / \mathrm{U}$ \\
\hline шт нові [14] & - & 17856,9 & 1312,7 & 65,1 & 7,35 & 16,6 \\
\hline орноземи передгірські [14] & - & 17813,9 & 1324,9 & 66,4 & 7,42 & 13,2 \\
\hline орноземи південні [14] & - & 17475,4 & 1295,0 & 65,2 & 7,41 & 16,9 \\
\hline ис ртьян & - & 17263,5 & 1289,3 & 62,4 & 7,47 & 20,3 \\
\hline $\begin{array}{l}\text { оричневі під лісом, } \\
\text { з к зник ис йя }\end{array}$ & - & 14735,2 & 1107,3 & 57,4 & 7,51 & 20,8 \\
\hline оричневі, переліг & - & 14017,9 & 1047,9 & 53,9 & 7,48 & 18,4 \\
\hline рунти клерів (р. 14) & 2000 & 13560,5 & 1007,7 & 51,5 & 7,47 & 17,3 \\
\hline оричневі, фортеця $\mathrm{p}$ кс & 2500 & 12899,6 & 967,5 & 49,3 & 7,50 & 22,5 \\
\hline оричневі фортеця емб ло & 500 & 12779,2 & 997,3 & 52,6 & 7,80 & 21,6 \\
\hline рунти клерів (р. 8) & 2000 & 12418,9 & 978,1 & 51,5 & 7,88 & 21,5 \\
\hline рунти клерів (р. 13) & 2000 & 11951,6 & 963,4 & 51,3 & 8,06 & 23,8 \\
\hline $\begin{array}{l}\text { ерново-к рбон тні, } \\
\text { фортеця } \quad \text { р кс }\end{array}$ & 2500 & 11184,7 & 958,3 & 53,0 & 8,57 & 42,4 \\
\hline рунти клерів (р. 10) & 2000 & 10938,7 & 984,6 & 54,8 & 9,00 & 34,6 \\
\hline $\begin{array}{l}\text { оричневі, з повідник } \\
\text { “ ерсонес } \\
\text { врійський” }\end{array}$ & 1000 & 10882,9 & 971,1 & 55,5 & 8,92 & 34,7 \\
\hline рунти клерів (р. 7) & 2000 & 10793,9 & 986,8 & 55,8 & 9,14 & 36,2 \\
\hline рунти клерів (р. 12) & 2000 & 10382,4 & 925,4 & 52,2 & 8,91 & 32,5 \\
\hline сип ртилерійської б т реї & 100 & 10184,6 & 974,3 & 58,3 & 9,57 & 43,8 \\
\hline
\end{tabular}

${ }^{1} \mathrm{G} / \mathrm{U}, \%$ - співвідношення вільної енергії до енергії крист лічної гр тки.

${ }^{2} \mathrm{u} / \mathrm{U}, \%$ - співвідношення безкремнеземної ч стини енергії крист лічної гр тки до з г льного зн чення енергії гр тки.

орівняння енергії крист лічної гр тки (U) т процентної ч стки співвідношення вільної енергії й енергії крист лічної гр тки (G/U) (див. т бл. 1), з свідчує, що повнопрофільні зон льні грунти м ють більші зн чення енергії крист лічної гр тки, проте в них менш ч стк вільної енергії, як може перетворюв тись у роботу. чевидно, причини цього - у хімічному т мінер логічному скл ді грунтів. т ких грунт х м л ч стк енергії, як вивільняється й може зумовлюв ти формув ння т ких вл стивостей грунтів, н які потрібно з тр тити б г то енергії, н прикл д, процеси звітрюв ння, формув ння гумусового горизонту, фізико-хімічні процеси, у тому числі кумулюв ння гумусу. ро цей ф кт необхідно п м'ят ти в ході розробки комплексу з ходів для поліпшення вл стивостей грунтів, у р зі їхнього сільськогоспод рського використ ння. вп ки, у молодих грунт х велик ч стк вільної енергії, що спричиняє вивільнення 
більшої ч стини енергії, як може перетворюв тися в роботу. тже, у молодих грунт х процеси формув ння основних вл стивостей грунтів відбув ються зн чно швидше. . овд т кож з зн ч в, що потенційн родючість грунтів обернено пропорційн до з п су їхньої внутрішньої енергії [10].

К н голошено р ніше, зміни сум рного зн чення енергії крист лічної гр тки (U) ч стково пов'яз ні з сум рною ч сткою енергії, що прип д $є$ н кремнезем [1]. д ними т бл. 1 можн зробити висновок, що н йбільш енергія гр тки, проте низьк ч стк безкремнеземної ч стини $(\mathrm{u} / \mathrm{U})$ вл стив профільним зон льним грунт м, які б г ті н 3 лишкові мінер ли, тоді як молоді грунти з невеликими зн ченнями енергії гр тки, одн к високою ч сткою безкремнеземної ч стини б г ті н новосформов ні мінер ли. К 3 зн чив . олобуєв: “ еред грунтів з м лою енергією гр тки спостеріг ються дуже великі розбіжності в скл ді новосформов них мінер лів: це грунти, що б г ті бо н к рбон т к льцію, бо н півтор окисли" [1, с. 91]. обто новоутворені грунти м ють гр тку зі зниженою енергією зв'язку з огляду н н явність 3 лишкових мінер лів, гр тк яких зн чно міцніш, тобто в жче руйнується. ч сом в ході грунтоутворення відбув ються процеси н копичення бо новоутворення вторинних мінер лів з підвищенням зн чень енергії крист лічної гр тки.

ля грунтів х р ктерні вищі зн чення енергії крист лічної гр тки мінер лів, ніж у грунтоутворюв льних пород х (т бл. 2). них зн чно збільшуються зн чення вільної енергії іббс , це свідчить, що вивільняється більш енергія, як витр ч ється н процеси грунтоутворення, у тому числі н ускл днення системи, док зом чого є більші зн чення ентропії в грунт х, ніж у грунтоутворюв льних пород х.

ермодин мічні т енергетичні х р ктеристики грунтоутворюв льних порід т грунтів

\begin{tabular}{|l|r|r|r|r|}
\hline \multicolumn{1}{|c|}{ озрізи } & $\begin{array}{c}\text { нергія } \\
\text { крист лічної } \\
\text { гр тки }\end{array}$ & \multicolumn{1}{c|}{$\begin{array}{c}\text { нергія } \\
\text { іббс }\end{array}$} & $\begin{array}{c}\text { нтропія, } \\
\text { к } / \text { жхгр д }\end{array}$ & \multicolumn{1}{c|}{$\begin{array}{c}\text { умус, } \\
\%\end{array}$} \\
\hline оричневі, розріз 4 & 13873,05 & 1052,29 & 55,5125 & 7,00 \\
\hline рунтоутворюв льн пород розрізу 4 & 11823,27 & 971,72 & 52,4955 & 2,83 \\
\hline рунти клерів, клер 62 & 12418,93 & 978,05 & 51,5423 & 4,27 \\
\hline рунтоутворюв льн пород клер 62 & 9454,31 & 891,99 & 51,7795 & 1,02 \\
\hline рунти клерів, клер 49 & 10938,71 & 984,56 & 54,8308 & 5,22 \\
\hline рунтоутворюв льн пород клер 49 & 9728,45 & 903,36 & 52,3302 & 1,40 \\
\hline
\end{tabular}

тже, високі зн чення швидкостей грунтоутворення н поч ткових ет п х пояснюють термодин мічними х р ктеристик ми грунтоутворюв льних порід. термодин мічними х р ктеристик ми зд тність гірських порід до грунтоутворення можн визн чити т ким рядом: в пняки $\rightarrow$ мергелі $\rightarrow$ червоно-бурі глини $\rightarrow$ глини т суглинки $\rightarrow$ глини $\rightarrow$ конгломер ти $\rightarrow$ пісковики. грунт х зн чно більші зн чення енергії крист лічної гр тки мінер лів і вільної енергії іббс, ніж у грунтоутворюв льних пород х. термодин мічних позицій грунтоутворення - це процес з кономірного збільшення термодин мічних т енергетичних х р ктеристик субстр ту, н якому формуються грунти. і збільшенням зн чень енергетичних т термодин мічних х р ктеристик у грунт х з ч сом темпи процесу грунтоутворення сповільнюються. 


\section{СПИСОК ВИКОРИСТАНОЇ ЛІТЕРАТУРИ}

1. олобуєв . . пыт р счет энергии крист ллической решетки почвенных минер лов / . . олобуев // очвоведение - 1968. - № 4. - . 89-93.

2. рунтозн вство: ідручник / [ . . ихоненко, . . орін, . . ктіонов т ін.; 3 ред. . . ихоненк ]. - . : ищ освіт, 2005. - 703 с.

3. зенс- итовск я . . очвы и р стительность тепного рым / . . зенситовск я. - . : $\quad$ ук , 1970. - 152 с.

4. орогокупец . . ермодин мик минер лов и минер льных $\mathrm{p}$ вновесий / . . орогокупец, . . рпов. - овосибирск : ук . 1984. - 184 с.

5. ргин . очвенно-хронологические исследов ния н ерекопском перешейке в рыму / . . ргин , . . их йлов // егіон льні проблеми кр їни: геогр фічний н ліз т пошук шляхів вирішення : зб. н ук. пр ць. - ерсон, 2009. .174-178.

6. ргін . . собливості процесу суч сного грунтоутворення н території р 6 тської стрілки / . . ргін // егіон льні проблеми кр їни: геогр фічний н ліз т пошук шляхів вирішення : зб. н ук. пр ць. - ерсон, 2011. - . 110-113.

7. $б$ луєв. . нергетичні і термодин мічні х р ктеристики гірських порід як пок зник їх зд тності до грунтоутворення / . . 6 луєв // кологія і природокористув ння. - 2003. - ип. 6. - .92-95.

8. уев . . рист ллоэнергетик к к основ оценки свойств твердотельных м тери лов / . . уев, . . оцелуев , . . онч ров. - б., 2006. - 325 с.

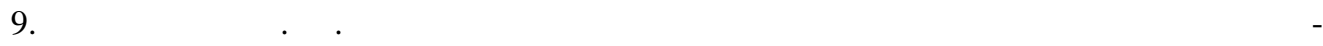
р льной ч сти почв / . . ск ндеров // очвоведение. - 1974. - № 4. .147-149.

10. $p$ петьяни . . сновные термодин мические конст нты неорг нических и орг нических веществ / . . р петьянц, . . р петьянц. - . : имия, 1968. $-470 \mathrm{c}$.

11. овд . . сновы учения о почв х / . . овд . - . : ук, 1973. - н. 1. $345 \mathrm{c}$.

12. очкин . . очвы, лес и клим т орного рым и пути их р цион льного использов ния / . . очкин // икит. бот. с д. - . : олос, 1967. - .38. 260 с.

13. бенеи. . рогноз изменений свойств почв и р зрушения минер лов под влиянием воды и р створов / . . бенец, . . орбунов, . . урин // очвоведение. - 1974. - № 4. - . 130-146.

14. оловицкий . . очвы рым и повышение их плодородия / . . оловицкий, . . усев. - имферополь : врия, 1987. - 152 с.

15. ермодин мические свойств индивиду льных веществ: спр вочное изд ние : в 4 т. / . . урвиц, . . ейц, . . едведев и др. - . : ук , 1982. - .4. H. $1 .-623 \mathrm{c}$.

16. ерсм н. . збр нные труды / . . ерсм н. - 1958. - . IV. - 517 с. 


\title{
ENERGY AND THERMODYNAMIC CHARACTERISTICS OF SOILS AND SUBSTRATES OF CRIMEAN PENINSULA
}

\author{
Olena Yergina \\ Taurida National V. I. Vernadsky University, \\ Academician Vernadsky Ave., 4, UA - 95007 Simferopol, Ukraine, \\ e-mail:YazcivLena@ramber.ru
}

The basic thermodynamic and energy characteristics substrates soils formations of different ages and soils of the Crimean peninsula considered. In developing strategies for remediation soils suppose to use thermodynamic parameters to assess the potential ability of formations rocks to soil. Proved that the thermodynamic position, process soil formation of autonomous increase energy and thermodynamic characteristics of the substrate on which soils formation.

Key words: lattice energy, Gibbs energy, entropy, soil.

\author{
лен ргин \\ врический н цион льный университет им. . . ерн дского, \\ просп. к демик ерн дского, 4, 95007, г. имферополь, кр ин , \\ e-mail: YazcivLena@rambler.ru
}

ссмотрено основные термодин мические и энергетические х р ктеристики почвообр зующих субстр тов и р зновозр стных почв рымского полуостров , которые возможно использов ть к к пок з тели потенци льной способности горных пород к почвообр зов нию и с мовосст новлению н рушенных почв при р зр ботке стр тегий рекультив ции земель. ок 3 но, что с термодин мических позиций, почвообр зов ние предст вляет собой процесс з кономерного увеличения термодин мических и энергетических х р ктеристик субстр т, н котором формируются почвы.

лючевые слов : энергия крист ллической решетки, свободн я энергия иббс , энтропия, почвообр зов ние. 